\title{
Design and Development of Alumni Career Information System using PHP MySQL
}

\author{
Mustofa Abi Hamid ${ }^{1}$, Didik Aribowo ${ }^{1}$, Rini Anggraini ${ }^{1}$ \\ ${ }^{1}$ Department of Electrical Engineering Vocational Education, Faculty of Teacher Training and Education, Universitas Sultan \\ Ageng Tirtayasa \\ E-mail: abi.mustofa@untirta.ac.id
}

\begin{abstract}
Alumni data collection at the Electrical Engineering Vocational Education Universitas Sultan Ageng Tirtayasa was still performed manually and there were no career information media about soft skills training and development, tracer studies, and job vacancies information. Therefore, media is needed to accommodate career information and alumni data collection quickly and effectively. The web-based information system using PHP MySQL was developed and tested for feasibility as an information medium for soft skills training and development, tracer studies, job vacancies information, as well as career counseling and consulting. This study used a Modifie $\mathrm{RnD}$ as a development method and the waterfall method as a development model consisted of analysis, design, coding (implementation), and testing. The testing was carried out by 37 people consisted of software experts, admins, alumni, and students of Electrical Engineering Vocational Education. The test was based on the ISO9126 standard with functionality, usability, reliability, and efficiency aspects. Based on the results, the functionality aspect had a score of 77 (very feasible), usability aspect had a score of 87.8 (very feasible), the reliability aspect had a score of $100 \%$ (very feasible) and the average page load time was 3.48 seconds (feasible).
\end{abstract}

Keywords: alumni career, information system, PHP MySQL, vocational higher education, website.

\section{INTRODUCTION}

Every university has a moral responsibility to ensure its graduates get a job fast. Alumni need soft skills training before entering the world of work and need up-to-date job vacancy information. Therefore, there a need of clear and updated information which can easily be accessed by everyone. Information media is needed about soft skills training and development, cooperation or partnerships with industry and universities, as well as information on job vacancies and tracer studies for alumni. This is expected to shorten the waiting period for graduates to get a job.

Tracer study is a university strategy to obtain information related to graduates [1]. Information is collected through tracer studies namely the waiting period for graduates to find a job, income (salary), employment history, change in the workplace, or career path. In addition, tracer studies also include alumni assessments of administrative services, learning, learning experiences, and involvement in research and community service, as well as facilities. Stakeholder assessments of alumni are related to integrity, expertise, problemsolving skills, communication skills, cooperation, and language skills [2]-[4]. This tracer study system can evaluate the educational process, measure educational goals, and make improvements in the future [1].

Therefore, it is necessary to have an information system to assist administrators to collect data on alumni of Electrical Engineering Vocational Education and as an information media for soft skills development and training, tracer studies, information on job vacancies, and career counseling and consulting. The information system for alumni career development is an Electrical Engineering Vocational Education service to students and alumni to improve the relevance of graduates in accordance with their study program or field through training and soft skill development activities so that they have a competitive 
advantage in entering the world of work and industry.

The web-based alumni career information system was using the CodeIgniter Framework [5][8] as an open-source application, with the PHP programming language, MySQL database, and Unified Modeling Language (UML) modeling and design [9]. UML is a modeling language for objectoriented systems [10]. The model was used to simplify complex problems to make them easier to learn and understand [11].

Several similar career development applications for alumni were developed by Arifin and Hendro [12] to accommodate input from graduate users for their relevance to the world of work using PHP MySQL. Heryati [13] developed a website-based e-career application using the System Development Life Cycle (SDLC). Alfarisyi, Rispianda, and Amila [14] developed a website to accommodate all information about alumni. Meanwhile Nasuha and Siahaan [15] analyzed and developed website-based alumni information system (tracer study). Romadhoni developed a websitebased alumni information system [16].

The existing applications and information systems were not equipped with information on soft skills training as well as industry and agency partners. Therefore, in this system, there will be information on soft skills training, industry partners, as well as career counseling and consulting. Alumni can fill out a tracer study questionnaire in the column provided on the website.

\section{METHODS}

The design of the alumni career development information system software used Research and Development (R\&D) method and the Waterfall model [17], [18]. The study was caried out on Electrical Engineering Vocational Education Universitas Sultan Ageng Tirtayasa with 37 respondents consisted of 2 software experts, 1 administrator, 8 alumni and 26 students of Electrical Engineering Vocational Education Universitas Sultan Ageng Tirtayasa. The data collection instruments were observation [19], in-depth interviews [20], and questionnaire [21], [22] to media experts, alumni, and students of Electrical Engineering Vocational Education.

According to Rosa \& Saladin, the main stages of the waterfall model [23], namely: analysis, design, coding (implementation), and testing. Feasibility testing was carried out using ISO 9126 standard [24], [25] Functionality aspect was tested using a checklist test case [26] on 2 media experts in the field of programming and web application design and security systems using the Acunetix web vulnerability scanner software [27] to automatically scan for common security attacks such as SQL Injection and Cross Scripting (XSS). The usability aspect was validated using a modified questionnaire instrument from Lund [28] on 1 administrator, 8 alumni, and 26 students. Reliability aspect was tested using WAPT Pro 5.0 by simulating as many visitors as possible on the system being tested until the server goes down or it is called stress testing. The efficiency aspect was tested using the GTMetrix online software [29].

The observed parameters were the number of data bytes, the number of HTTP requests, GZIP compression, minification, final score, and so on. The Page Speed application from Google was used to test the loading speed of a website. The study flowchart can be seen in Figure 1.

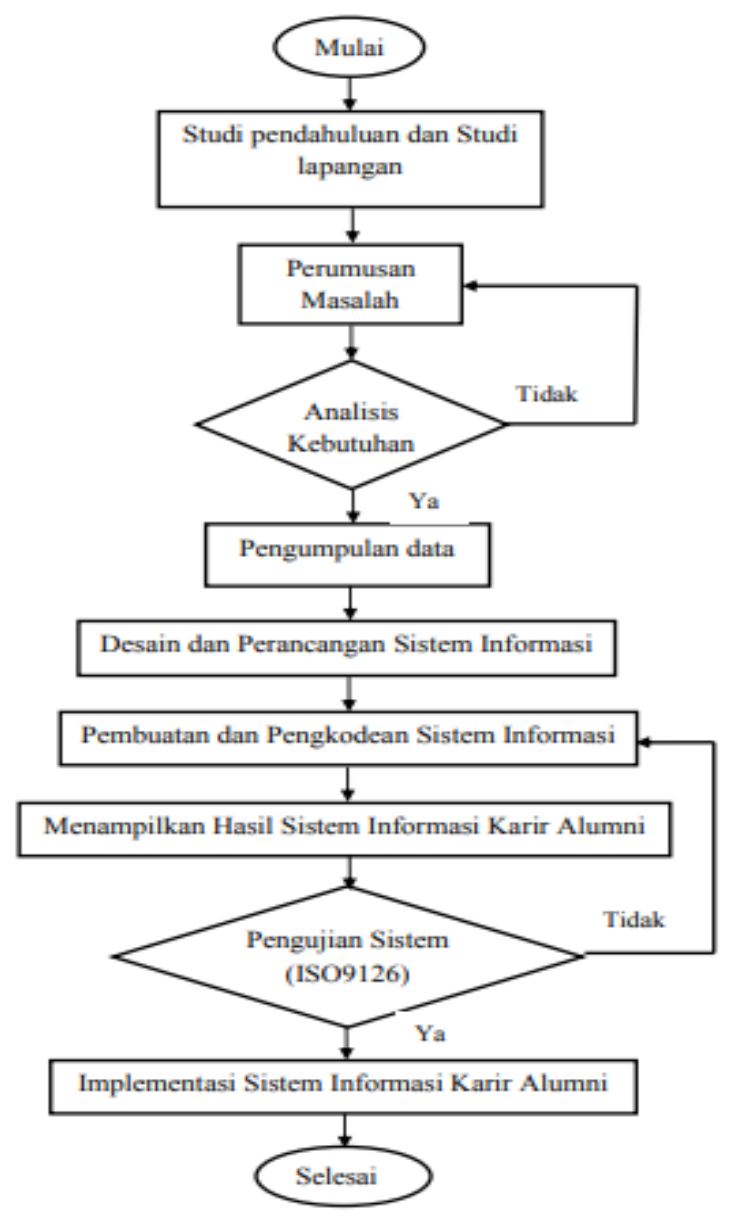

Figure 1. Study Flowchart 
The data analysis technique used was in accordance with the feasibility testing aspects of the ISO 9126 standard. The functionality aspect refers to the feature completeness matrix by Archarya $\&$ Sinha:

$$
X=\frac{\mathrm{I}}{\mathrm{P}}
$$

With $\mathrm{X}$ as functionality, I as the number of features implemented successfully, and $\mathrm{P}$ as the number of features designed. Software is said to be good if it meets $0 \leq X \leq 1$. Software is said to have met the standards if $\mathrm{X}$ is more than 0.5 and approaches 1 .

In the security system, there are 3 software security levels namely low (high security), medium (medium security), and high (low security). A security system is said to be feasible if it is a medium or low levels.

Usability aspect was tested using a Likert scale [30] with 4 points from Strongly Disagree (1) to Strongly Agree (4) as response options for all items. The score was analyzed by calculating the average answer based on the scoring of each answer using the following formula [31]:

$$
X=\frac{\Sigma \mathrm{x}}{\mathrm{n}}
$$

With $\mathrm{X}$ as the average score for each aspect or all aspects, $\Sigma \mathrm{x}$ as the total score for each aspect or all aspects, and $\mathrm{n}$ as the number of respondents. The results obtained were then presented according to the feasibility test criteria in Table 1.

Table 1. Conversion of quantitative to qualitative data

\begin{tabular}{lcc}
\hline No. & \multicolumn{1}{c}{ Score } & Category \\
\hline 1. & $x \geq \bar{x}+1 . S B x$ & Very Feasible \\
2. & $\bar{x}+1 . S B x>x \geq \bar{x}$ & Feasible \\
3. & $\bar{x}>x \geq \bar{x}-1 . S B x$ & Infeasible \\
4. & $x<x-1 . S B x$ & Very \\
& & Infeasible \\
\hline
\end{tabular}

\section{Description:}

$x$ : Average score

$\bar{x}:$ Score achieved

$S B x:$ Standard deviation
The website reliability score was tested using the Web Application Load, Stress, and Performance Testing (WAPT) software. The calculation results in the software were compared with the Telcordia standard. If more than $95 \%$, the system tested has met the reliability aspect [32].

The efficiency test was intended for the time behavior sub-characteristic, namely testing the web speed for responding and processing the desired command. The loading time was measured using an interpretation by J. Nielsen which limits the loading time to a maximum of 10 seconds [33].

Table 2 shows the score and grade classification table based on Yslow [34]. If the tested system gets a final score of $\mathrm{D}$, then the system is declared to be very good in terms of efficiency [35].

Table 2. YSlow score classification and grade

\begin{tabular}{ccc}
\hline No. & Score & Grade \\
\hline 1. & $90-100$ & A \\
2. & $80-89$ & B \\
3. & $70-79$ & C \\
4. & $<60$ & D \\
\hline
\end{tabular}

\section{RESULT AND DISCUSSION}

The career information system for the alumni underwent 4 stages namely the analysis, design, implementation (coding), and testing stages. The stage analysis was carried out with observations to the Electrical Engineering Vocational Education Untirta, and interviews with the administration section of the Electrical Engineering Vocational Education Untirta about alumni data and alumni career information systems. The survey was also carried out on alumni career information systems at several universities which already have their website-based alumni careers information systems such as UNY, UPI, UNPAD, and UNSRI, but only limited to the system interface [7]. Based on the results of observations and interviews, the system applied 
in the Electrical Engineering Vocational Education Untirta was still manual.

The design stage was started by designing data designs such as Entity Relationship Diagram (ERD) design, logical database design, and physical database [36]. ERD design can be seen in Figure 2.

The logical database was implemented in the form of tables. Each table contains related columns based on a MySQL database. Architectural design was carried out using UML diagram with Astah Professional version 8.1.0 [37].

UML diagrams used were class diagrams, use case diagrams, activity diagrams and sequence diagrams. The use case diagram describes the actors involved with the developed software and its processes. The activity diagram describes the process analysis of a use case diagram.

The sequence diagram describes the interactions between objects in and around the system (including users, displays, etc.) in the form of messages against time. The sequence diagram consists of vertical (time) and horizontal (related objects) dimensions.

The implementation stage aims to produce a design to be implemented in a programming language to produce a web-based alumni career information system. The programming code was created with Sublime Text 3 software, with the PHP programming language and the CodeIgniter framework using the Model-View-Controller (MVC) design pattern [38].
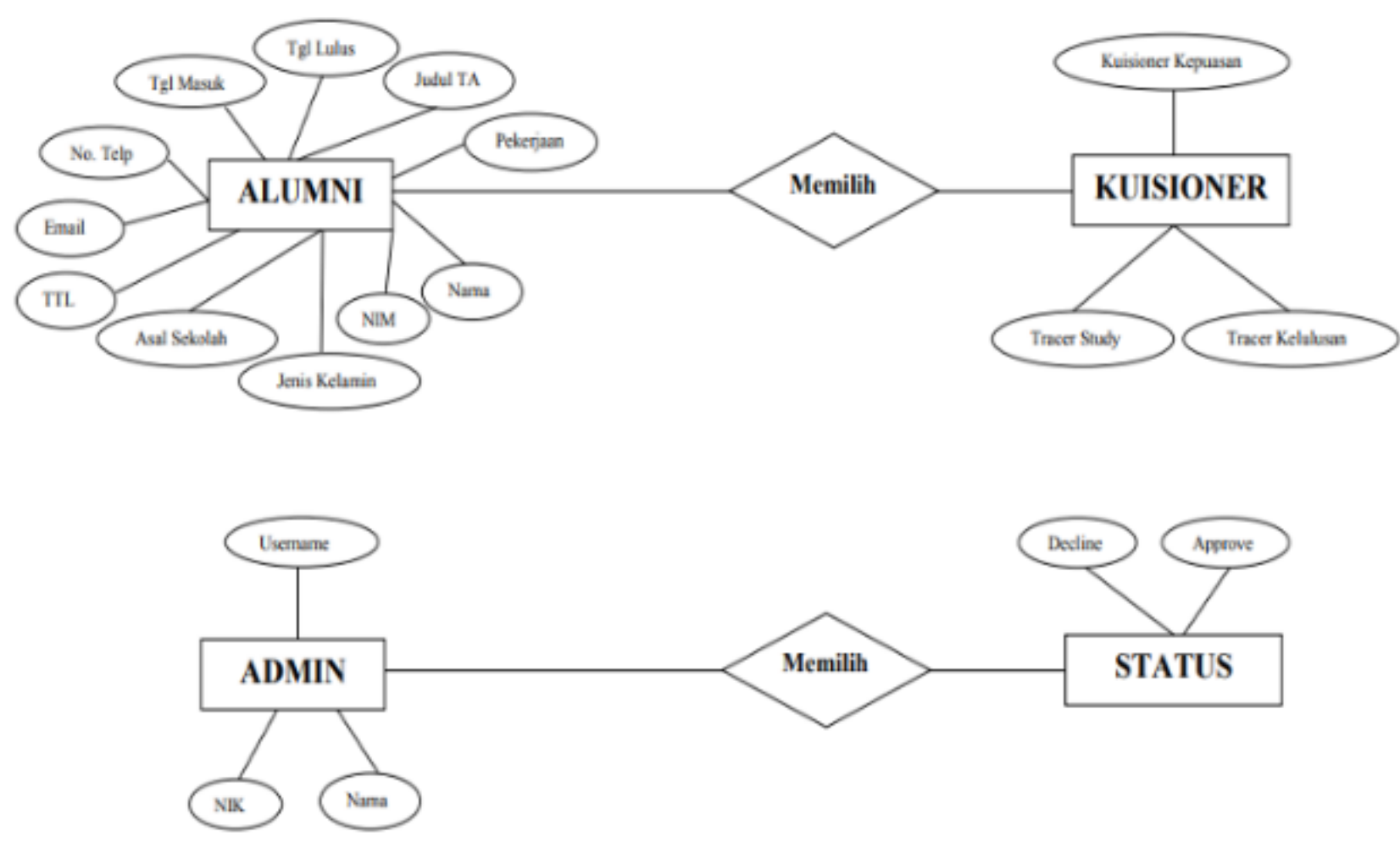

Figure 2. ERD Design 


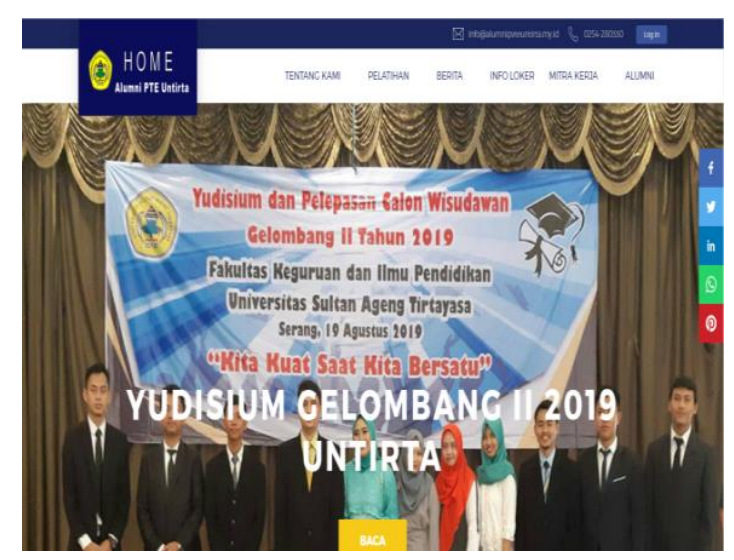

Figure 3. Main Page (Interface)

The main page is the first page accessed on the alumni career information system website. The main page contains information highlights as well as the latest news with photos and news articles to be shared on social media platforms.

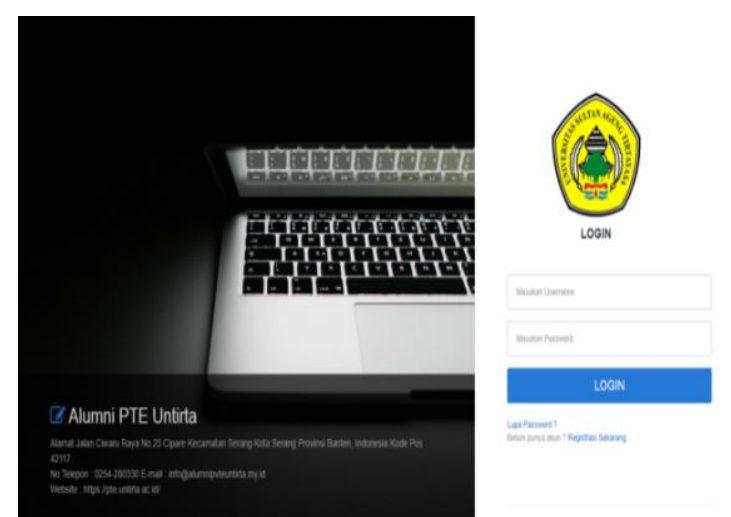

Figure 4. Login Page

The login page on the alumni career information system is used by users to enter the system. There is a display of username, password, account registration, and forgot password on the login screen. The administrator account uses the admin username with a pre-set password, while alumni and other users use an email with a password in the form of their respective NIM (Student Identification Number). To enter the system using an alumni account, alumni are required to register an account first by filling in their full name (for username), student identification number, and email to be verified by the administrator.

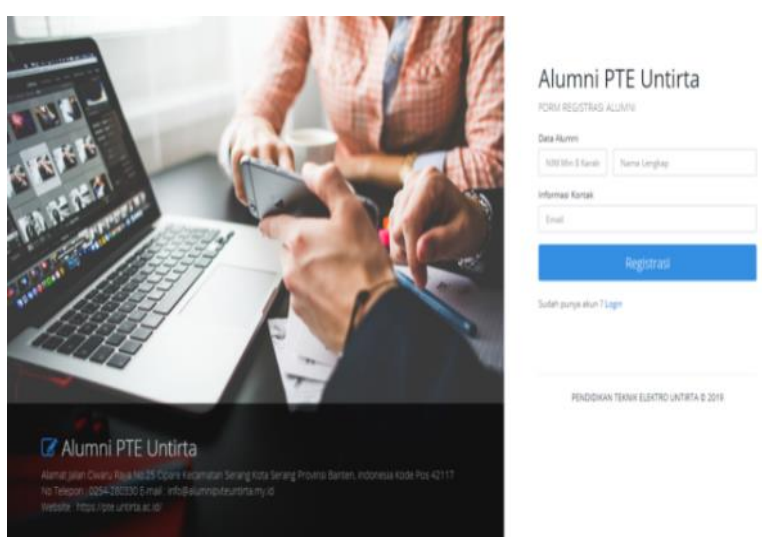

Figure 5. Alumni Registration Page

The alumni registration page is used by alumni to obtain the account (username and password).

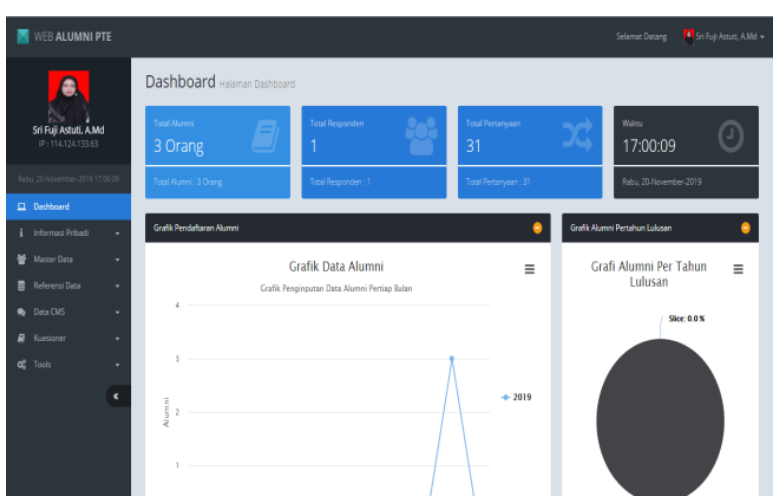

Figure 6. Admin Dashboard Page

Admin dashboard page on the alumni career information system is used by admins to access certain menus.

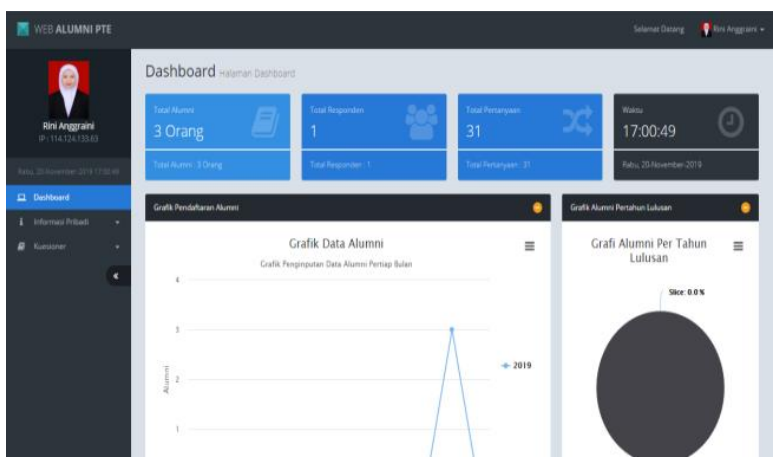

Figure 7. Alumni Dashboard Page

Alumni dashboard page on the alumni career information system is used by admins to access certain menus. 


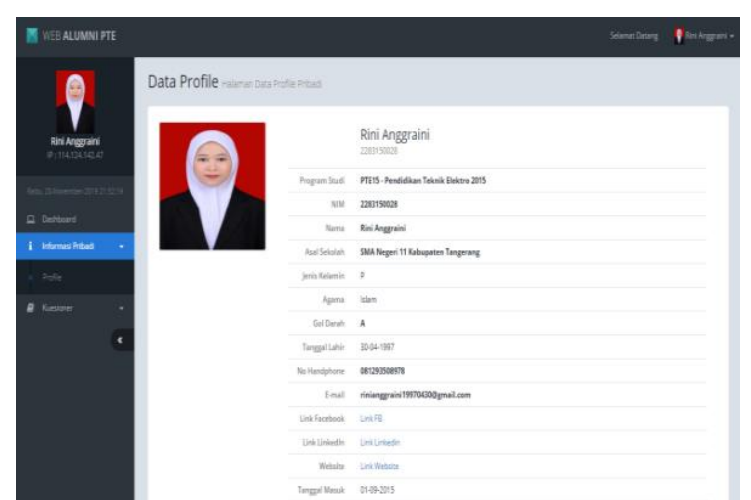

Figure 8. Alumni Profile Page

The alumni profile page in the alumni career information system is used by alumni to change alumni profiles, send testimonial messages and change the password.

The testing phase aimed to test the feasibility of the alumni career information system using the blackbox method and referring to the ISO 9126 model on functionality, usability, reliability, and efficiency aspects [39]. At the testing stage, the results achieved by several aspects are briefly described as follows:

\section{A. Functionality Aspect}

The media expert assessment on the functionality aspect can be seen in Table 3 .

Table 3. The media expert assessment on the functionality aspect

\begin{tabular}{lccc}
\hline No. Respondents & $\begin{array}{c}\text { Number of } \\
\text { Website } \\
\text { Function } \\
\text { Questions }\end{array}$ & Category \\
\hline 1. & Expert 1 & 77 & Very Feasible \\
2. & Expert 2 & 77 & Very Feasible \\
\hline
\end{tabular}

Based on table 3 , the function of an alumni career information system website had a score of 77 and was in "very feasible" category. The category of feasibility can be seen in table 2. The security sub-character test was carried out using the Acunetix Vulnerability Web Scanner software with the results in Figure 9.

Based on the security aspect testing with the Acunetix Vulnerability Web Scanner software, the information system had threat level 2 (Medium) showing medium vulnerability (less secure). Therefore, the alumni career information system security system needs to be improved.

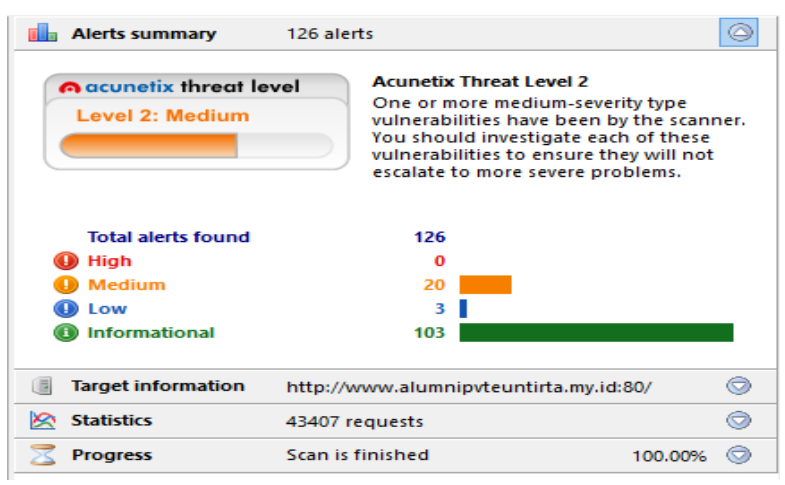

Figure 9. Security Testing Results

\section{B. Usability Aspect}

The usability testing results can be seen in Table 4.

Table 4. The expert assessment on the usability aspect

\begin{tabular}{cccc}
\hline No. & Respondents & Total & Category \\
\hline 1. & Expert 1 & 70 & Very Feasible \\
2. & Expert 2 & 69 & Very Feasible \\
\multicolumn{2}{c}{ Average Score } & 69.5 & Very Feasible \\
\hline
\end{tabular}

Based on Table 4, the usability aspect had a score of 69.5 or was in the "Very Feasible" category. Meanwhile, the respondent assessment can be seen in Table 5:

Table 5. The Respondent Assessment

\begin{tabular}{ccc}
\hline Total Score & Average Score & Category \\
\hline 3074 & 87.8 & $\begin{array}{c}\text { Very } \\
\text { Feasible }\end{array}$ \\
\hline
\end{tabular}

Based on Table 5, the respondent assessment on the feasibility of the alumni career information system website had an average score of 87.8 or was in the "Very Feasible" category. The category of feasibility can be seen in table 1 . 


\section{Reliability Aspect}

The results of the alumni career information system test (http://www.alumnipvteuntirta.my.id/) using WAPT with 5 users for 10 minutes can be seen in Table 6.

Table 6. Reliability Test Results

\begin{tabular}{llc}
\hline No. & \multicolumn{1}{c}{ Profile } & $\begin{array}{c}\text { Reliability } \\
\text { Results }\end{array}$ \\
\hline 1. & Successful sessions & 15498 \\
2. & Failed sessions & 0 \\
3. & Successful Pages & 15498 \\
4. & Failed pages & 0 \\
5. & Successful hits & 15498 \\
6. & Failed hits & 0 \\
7. & Total kb sent & 5404 \\
8. & Total kb receive & 108622 \\
\hline
\end{tabular}

It can be concluded that all components on the reliability test had a success of $100 \%$ and had met the $95 \%$ Telcordia standard.

\section{Efficiency Aspect}

The results of efficiency test using GTMetrix web-based software can be seen in Table 7.

Table 7. Efficiency Test Results

\begin{tabular}{|c|c|c|c|}
\hline No. & Web Page & $\begin{array}{c}\text { Page } \\
\text { Load } \\
\text { Time } \\
\text { (second) }\end{array}$ & Slow Grade \\
\hline 1. & Main & 3.5 & $60 \%$ (D) \\
\hline 2. & Login & 3.1 & $81 \%(\mathrm{~B})$ \\
\hline 3. & Dashboard & 3.5 & $81 \%$ (B) \\
\hline 4. & $\begin{array}{l}\text { Forgot } \\
\text { Password }\end{array}$ & 3.8 & $81 \%(\mathrm{~B})$ \\
\hline \multirow[t]{2}{*}{5.} & Registration & 3.5 & $74 \%(\mathrm{C})$ \\
\hline & Average & 3.48 & $75.4 \%(\mathrm{C})$ \\
\hline
\end{tabular}

Based on table 7, the average web page loading time was 3.48 seconds. In addition, each page load time did not exceed 10 seconds (feasible).

\section{CONCLUSION}

This media is expected to be able to accommodate all alumni of Electrical Engineering Vocational Education Untirta data collection in a more computerized and effective manner. In addition, this media is expected to provide career-related information for alumni, students, and all those who need career-related information related to the Electrical Engineering Vocational Education Untirta. Based on the feasibility test, the website was feasible and can be used by the public.

However, the security aspect was still not secure and the resulting page load average was still more than 3 seconds. To improve the test results, it can then be performed with stronger security and implement application caching techniques so that security can be more maintained and the resulting page load can be reduced from 3 seconds.

\section{REFERENCES}

[1] H. Yuliansyah and L. Zahrotun, "Designing web-based data mining applications to analyze the association rules tracer study at university using a FOLD-growth method," Int. J. Adv. Comput. Res., vol. 6, no. 27, pp. 215221, Oct. 2016.

[2] N. Fajaryati, D. Santoso, S. Waluyanti, and A. A. Baiti, "Studi Penelusuran Alumni Teknik Elektronika D3 sebagai Upaya Peningkatan Mutu Penyelenggaraan Program Studi," Elinvo (Electronics, Informatics, Vocat. Educ., vol. 3, no. 1, pp. 25-30, Jul. 2018.

[3] A. C. Gines, "Tracer Study of PNU Graduates," Am. Int. J. Contemp. Res., vol. 4, no. 3, pp. 81-98, 2014.

[4] P. W. Yunanto, A. Idrus, V. M. Santi, and A. S. Hanif, "Tracer study information system for higher education," IOP Conf. Ser. Mater. Sci. Eng., vol. 1098, no. 5, p. 052107, Mar. 2021.

[5] A. Griffiths, CodeIgniter 1.7 
Professional Development. Packt Pub., 2010.

[6] M. T. Muslihi, "Development and functional testing on codeigniter framework based academic system."

[7] A. N. Hidayati, "Analisis perancangan sistem informasi tracer study berbasis web dengan menggunakan codeigniter," Skripsi, Progr. Stud. Pendidik. Tek. Inform. Fak. Tek. Univ. Negeri Yogyakarta, 2014.

[8] A. K. Himawan, "Performance analysis framework codeigniter and CakePHP in website creation," Int. J. Comput. Appl., vol. 94, no. 20, 2014.

[9] K. Siau and Q. Cao, "Unified Modeling Language," J. Database Manag., vol. 12, no. 1, pp. 26-34, Jan. 2001.

[10] S. Lee, "Unified Modeling Language (UML) for Database Systems and Computer Applications," Int. J. Database Theory Appl., vol. 5, no. 1, pp. 157-164, 2012.

[11] Adi Nugroho, Algoritma dan Struktur Data dalam Bahasa Java. Andi Offset, 2008.

[12] M. Arifin and R. H. H. HS, "Perancangan Sistem Informasi Pusat Karir Sebagai Upaya Meningkatkan Relevansi Antara Lulusan Dengan Dunia Kerja Menggunakan UML," IC-Tech, vol. 12, no. 2, 2017.

[13] A. Heryati and E. Erduandi, "SISTEM INFORMASI PENGEMBANGAN KARIR MAHASISWA UNIVERSITAS INDO GLOBAL MANDIRI," J. Inform. Glob., vol. 8, no. 2, 2018.

[14] M. I. Alfarisyi, R. Rispianda, and K. Amila, "Rancangan sistem informasi layanan alumni ITENAS berbasis web," Reka Integr., vol. 2, no. 1, 2014.

[15] A. Nasuha and K. Siahaan, "Analisis Dan Perancangan Sistem Informasi Alumni (Tracer Study) Berbasis Web Pada Iain Sulthan Thaha Saifuddin Jambi," $J$. Manaj. Sist. Inf., vol. 1, no. 1, pp. 18-29, 2016.

[16] E. N. A. Romadhoni, T. Widiyaningtyas, and U. Pujianto, "Implementasi Model
Waterfall Pada Pengembangan Sistem Informasi Alumni SMKN 1 Jenangan Ponorogo," SESINDO 2015, vol. 2015, 2015.

[17] K. Petersen, C. Wohlin, and D. Baca, "The Waterfall Model in Large-Scale Development," 2009, pp. 386-400.

[18] A. A. A. Adenowo and B. A. Adenowo, "Software Engineering Methodologies: A Review of the Waterfall Model and Object-Oriented Approach," Int. J. Sci. Eng. Res., vol. 4, no. 7, pp. 427-434, 2013.

[19] C. R. Greenwood, J. J. Carta, and H. Dawson, "Ecobehavioral Assessment Systems Software (EBASS): A system for observation in education settings.," 2000 .

[20] J. Arthur, Research methods and methodologies in education. Sage publications, 2012.

[21] S. Roopa and M. Rani, "Questionnaire Designing for a Survey," J. Indian Orthod. Soc., vol. 46, pp. 273-277, Oct. 2012.

[22] B. Gillham, Developing a questionnaire. A\&C Black, 2008.

[23] A. S. Rosa and M. Shalauddin, "Modul Pembelajaran Rekayasa Perangkat Lunak (Terstruktur dan Berorientasi Objek)," 2011.

[24] B. Behkamal, M. Kahani, and M. K. Akbari, "Customizing ISO 9126 quality model for evaluation of B2B applications," Inf. Softw. Technol., vol. 51, no. 3, pp. 599-609, Mar. 2009.

[25] S. N. Bhatti, "Why quality?," $A C M$ SIGSOFT Softw. Eng. Notes, vol. 30, no. 2, pp. 1-5, Mar. 2005.

[26] Z. Yang, Q. Li, H. Xie, Q. Wang, and W. Liu, "Learning representation from multiple media domains for enhanced event discovery," Pattern Recognit., vol. 110, p. 107640, Feb. 2021.

[27] J. Fonseca, M. Vieira, and H. Madeira, "Testing and Comparing Web Vulnerability Scanning Tools for SQL Injection and XSS Attacks," in 13th Pacific Rim International Symposium on 
Dependable Computing (PRDC 2007), 2007, pp. 365-372.

[28] T. A. Ghaffur, "ANALISIS KUALITAS SISTEM INFORMASI KEGIATAN SEKOLAH BERBASIS MOBILE WEB DI SMK NEGERI 2 YOGYAKARTA," Elinvo (Electronics, Informatics, Vocat. Educ., vol. 2, no. 1, pp. 94-101, Oct. 2017.

[29] D. Andriansyah, "No Title," Comput. Based Inf. Syst. J., vol. 7, no. 1, p. 23, Mar. 2019.

[30] P. D. Sugiyono, "Metode Penelitian Pendidikan Pendekatan Kuantitatif, Kualitatif, dan R\&D Bagian III.” Bandung: Alfabeta. Cv, 2015.

[31] D. Mardapi, "Pengukuran Penilaian dan Evaluasi Pendidikan Edisi 2," Yogyakarta Parama Publ., 2017.

[32] A. Asthana and J. Olivieri, "Quantifying software reliability and readiness," in 2009 IEEE International Workshop Technical Committee on Communications Quality and Reliability, 2009, pp. 1-6.

[33] J. Nielsen, "Website response times (2010)," URL http//www. nngroup. com/articles/website-responsetimes/(visited 10/29/2014), 2011.

[34] R. Kumar and N. Hasteer, "Evaluating usability of a web application: A comparative analysis of open-source tools," in 2017 2nd International Conference on Communication and Electronics Systems (ICCES), 2017, pp. 350-354.

[35] R. S. Nastiti, "Sistem Informasi Pelanggaran Siswa Berbasis Web Pada SMA Negeri 1 Bawang Banjarnegara," Lap. Skripsi. Univ. Negeri Yogyakarta, 2015.

[36] E. Diana, "Analisis Dan Perancangan Sistem Informasi Tracer Study Berbasis Web," J. Ilm. Media Sisfo, vol. 11, no. 2, pp. 817-829, 2017.

[37] N. Azwanti, "SISTEM INFORMASI PENJUALAN TAS BERBASIS WEB DENGAN PEMODELAN UML," KLIK - Kumpul. J. ILMU Komput., vol. 4, no.
1, p. 1, Feb. 2017.

[38] E. C. Nugroho, "Sistem Pusat Karir dan Tracer Study Perguruan Tinggi," IJNSIndonesian J. Netw. Secur., vol. 7, no. 1, 2017.

[39] T. N. Sari, “ANALISIS KUALITAS DAN PENGEMBANGAN SISTEM INFORMASI AKADEMIK BERBASIS WEB MENGGUNAKAN STANDARD ISO 9126," JIKO (Jurnal Inform. dan Komputer), vol. 1, no. 1, Feb. 2016. 